\title{
Determinant of Carbon Emission Disclosure at Mining Companies Listed in Indonesia Stock Exchange
}

\section{Nanies Putri Halimah and Heri Yanto}

Department of Accounting, Faculty of Economics, Universitas Negeri Semarang L2 Building, 2nd Flor FE UNNES, Sekaran College, Gunungpati, Semarang, 50229

\section{Abstract}

This study aims to examine and obtain empirical evidence on determinants of carbon emissions disclosure at mining companies listed in Indonesia Stock Exchange. Several factors involved in this study, there are leverage, profitability, firm size, and institutional ownership. In addition, population of this study is 41 mining companies listed in Indonesia Stock Exchange. Meanwhile, sample is selected using purposive

Corresponding Author: Nanies Putri Halimah naniesputri@gmail.com

Received: 7 August 2018 Accepted: 15 September 2018 Published: 22 October 2018

Publishing services provided by Knowledge $\mathrm{E}$

(c) Nanies Putri Halimah and Heri Yanto. This article is distributed under the terms of the Commons Attribution License, which permits unrestricted use and redistribution provided that the original author and source are credited.

Selection and Peer-review under the responsibility of the ICE-BEES 2018 Conference Committee.

\section{G OPEN ACCESS} sampling technique which produced 56 unit of analysis. This study also uses content analysis techniques on annual reports and/or sustainability reports in 4 years to measure carbon emission disclosure. Data collection is conducted by documentation technique. Moreover, multiple rank regression with SPSS version 23 applications is executed to analyze the data. Results indicate that leverage, profitability, firm size, and institutional ownership have significant and negative effect on carbon emission disclosure. Therefore, it can be concluded that the higher leverage, profitability, firm size, and institutional ownership of the company, carbon emission disclosure which is reported by mining companies in Indonesia will be lower.

Keywords: Carbon Emission Disclosure; Firm's Size; Institutional Ownership; Leverage; Profitability

\section{Introduction}

Global warming and public concerns about disasters caused by global warming that could endanger living creatures remains an international hot topic [5]. Based on observations by National Aeronautics and Space Administration (NASA), earth temperature has continuously increased and in January to September 2016, earth temperature reached out the hottest level for 35 years [28]. Specifically, global warming is a phenomenon of increasing global temperature due to greenhouse gas effect produced by 
increased emissions of gases such as carbon dioxide $\left(\mathrm{CO}_{2}\right)$, methane $\left(\mathrm{CH}_{4}\right)$, dinitrooksida ( $\mathrm{N}_{2} \mathrm{O}$ ), and chlorofluorocarbons (CFC) which cause solar energy is being trapped in the atmosphere (Riebeek 2010, in [4]).

This increasingly dangerous global warming is driven by greenhouse gas emissions produced by human actions. The most dangerous increase in greenhouse gases is caused by $\mathrm{CO}_{2}$ emissions released through human activities, such as deforestation, fossil fuel use, increased industrial quantities and natural processes including respiration and volcanic eruptions. Unfortunately, our planet capacity to process this waste has been greatly weakened by widespread and more destruction of the world's forests [32].

World Resources Institute (WRI) on its official website stated that Indonesia ranks 6th world largest contributing country of carbon emissions in 2014, after United States, European Union, China, India and Russia. The amount of carbon emissions contributed by Indonesia in 2014 amounted to 2.05 billion Mt COze. Furthermore, world's concern about climate change due to increased concentrations of greenhouse gases has prompted the emergence of an international agreement called Kyoto Protocol in 1997. Indonesia ratified the first Kyoto Protocol on 28 June 2004 through Law no. 17 in 2004. Then in 2011 , Indonesia also issued presidential regulations as legal basis for the implementation of greenhouse gas emission

reduction. There are Presidential Regulation No. 61 on National Action Plan for Greenhouse Gas Emission Reduction (RAN-GRK) and Presidential Regulation No. 71 of 2011 on the Implementation of National Greenhouse Gas Inventory (Supriadi et al., 2016).

Existing regulations lead Indonesian entities that contribute to carbon emissions in the air participate in supporting the government to achieve its goal of reducing carbon emissions by 2030. Their participation is reflected in information disclosure of carbon emissions through annual report and sustainability report. However, currently carbon emissions disclosure practices in Indonesia is voluntary disclosure [25]. Non-financial companies in Indonesia Stock Exchange which disclose carbon emission during 20102012 is 37 from 339 companies and 32 companies from 332 total companies in the period of 2012-2014 [1, 19].

Previous research on carbon emission disclosure showed inconsistent results, thus researchers interested to elaborate more. For instance, research by Bae Choi et al., 
(2013) on carbon emissions disclosure in Australian companies showed that leverage and profitability do not affect carbon emissions disclosure, while firm size, industry type, carbon emission level, and quality of corporate governance have significant effect on carbon emission disclosure.

Jannah \& Muid (2014) analyzed factors that influence Carbon Emission Disclosure in Indonesian companies. They found that leverage has significant and negative effect to carbon emission disclosure, whereas firm size, profitability, media exposure and industry type have significant and positive impact. Moreover, environmental performance in their study demonstrated no significant effect on carbon emissions disclosure.

In addition, Akhiroh \& Kiswanto (2016) executed a research entitled Determinant of Carbon Emission Disclosure. Results indicated that profitability,

organizational visibility, managerial ownership and audit committee have significant and positive impact, while environmental performance, financial distress, institutional ownership, and independent commissioners have no effect on carbon emission disclosure.

Jaggi et al., (2017) also conducted a study entitled The Factors Motivating Voluntary Disclosure of Carbon Information: Evidence Based on Italian Listed Company which showed that environmental committees, institutional ownership and emission treding scheme significantly and positively affect carbon information disclosure. Meanwhile, proportion of independent directors found to not have any effect.

Based on the backrgound and previous research that show inconsistencies results, researcher wants to re-examine the factors that affect carbon emission disclosure. Basically, this study is conducted by referring to previous researches on carbon emission disclosure. The study aims to analyze the effect of leverage, profitability, firm size, and institutional ownership. Originality of this research lies in its research object, which is mining company listed in Indonesia Stock Exchange (BEI) during the period of 2013-2016. Throughout the researcher's knowledge, no research has been executed on factors affecting carbon emission disclosure at mining companies listed in BEl during the period of 2013-2016.

There are three theories supporting this study. First, theory of legitimacy. Dowling \& Pfeffer (1975) provided a view of the theory of legitimacy that an organization strives to build harmony between the social values associated with their activities and acceptable behavioral norms on a larger social system in which their organization exists. Organizational legitimacy can be obtained if these two value systems are aligned. Therefore, company will disclose carbon emissions in its annual report or sustainability 
report to aware the public that its operation is consistent with surrounding community values.

Stakeholder theory said that a company is not an entity that operates for its own business only but it should provide benefits to its stakeholders. The existence of a company is strongly influenced stakeholders supports to the company (Ghozali \& Chariri, 2007 in [19]). Thus, when stakeholders take control of important economic resources, companies will seek to meet the needs of stakeholders (Ullman, 1985 in [36]).

Jensen \& Meckling (1976) defined agency relationships as contracts between one or more principal with agents to perform services (ex.: managing companies) including providinge the agents of authority as decision makers. There is, however, a strong reason that agents will not always act in the best interests of the principal. This condition could trigger information asymmetry.

Information asymmetry occured when management has information on a company that is not owned by an outsider [10]. Therefore, companies are expected to make voluntary disclosures about company information, such as environmental issues which in this case is carbon emissions disclosure. By doing this, it is expected to minimize information asymmetry between agents and principals.

Leverage describes company's assets and financial risks that become expense in the future [27]. Greater leverage ratio reflects higher company's debt value [3]. According to stakeholder theory, creditor is one of stakeholders who has power to influence the company. If the leverage ratio is greater, creditor will give more pressure to the company. Research conducted by Irwhantoko \& Basuki (2016) and Peng et al., (2014) showed that leverage has significant and negative effect on carbon emission disclosure. Thus, firms with high leverage tends to concentrate more on repaying their debts by making non-mandatory disclosures. Based on this, the hypothesis is:

\section{$H_{1}$ : Leverage has significant effect on Carbon Emisssion Disclosure.}

Profitability is a ratio to determine the effectiveness and efficiency of a company in managing all its assets to generate profit [16]. Profitability reflects company's financial performance. Companies with poor financial performance will give extra focus on achieving financial goals and improving their performance, and thus cause their capabilities in preventing and reporting carbon emissions become limited [30]. This study uses ROA ratio to calculate profitability. ROA is chosen because it can describe efficiency of the company in using its asset to gain profit. 
According to the theory of legitimacy, society requires company to conduct social responsibility to the surrounding environment. Good corporate performance will affect how fast company responses to the issue. Companies with better performance will have greater ability for disclosure and having more details disclosure area as well (Roberts, 1992 in [17]).

There are three different results of previous research. Cahya (2016) and Jannah \& Muid (2014) found that profitability affects carbon emission disclosure. However, Bae Choi et al., (2013) showed that carbon emission disclosure is not affected by profitability. Moreovre, Yanto \& Muzzammil (2016) also found the difference, that is, there is a negative relationship between profitability to environmental disclosure. It means that greater level of profitability will cause more limited disclosure for environmental information od the company.

Based on the theory and results of previous research, it can be concluded that companies with good profitability will be able to provide additional employee or financial resources for voluntary disclosure. Therefore, companies with good financial performance are expected to engage in carbon emissions disclosure. So, the hypothesis is as follows:

\section{$\mathrm{H}_{2}$ : Profitability has significant effect on carbon emission disclosure.}

Firm size represents company's resources, means the larger the company's size the greater its resources [7]. People have higher expectations about carbon management practices by large companies. Therefore, large companies are more responsive in meeting disclosure demands (Freedman \& Jaggi, 2005 in [23]). Based on the theory of legitimacy, large firms have a greater tendency to disclose information about carbon emissions. Larger companies are getting higher pressure from the community and stakeholders. In addition, large company also avoid huge cost due to community demands in the future [26].

Jannah \& Muid (2014) showed that firm size has significant and positive effect on carbon emission disclosure. Nevertheless, Dibia \& Onwuchekwa (2015) found negative and significant relationship between firm size and oil and gas environment disclosure in Nigeria. Based on the findings and theories above, the researchers concluded that larger firm size driven company to disclose more about its carbon emissions. Below is the hypothesis:

\section{$\mathrm{H}_{3}$ : Firm size has significant effect on carbon emission disclosure.}


Relationship between institutional ownership and carbon emissions disclosure may come into debates. According to agency theory, in the positive side, institutional ownership can be an effective control mechanism in every decision taken by management [31]. As a result, managers are under pressure to always meet the information needs of investors, including carbon information [18]. On the other hand (from a negative perspective), high institutional ownership can influence companies to reduce the disclosure of voluntary corporate information or manipulate disclosures to maximize their personal benefits. This kind of conflict is known as the principal agency which produce an agency problem between majority and those minority shareholder [13].

Previous studies also found contrary results. Chang \& Zhang (2015) stated that companies with a large proportion of institutional ownership will voluntarily disclose more environmental information. Whereas, Akhiroh \& Kiswanto (2016) showed that institutional ownership has no effect on carbon emissions disclosure. Furthermore, Alhazaimeh et al. (2014) found that there is significant and negative relationship between block holder ownership (which is proxied by institutional ownership) with voluntary disclosure. Thus, hypothesis that can be formulated by is as follows:

$H_{4}$ : Institutional ownership has significant effect on Carbon Emission Disclosure.

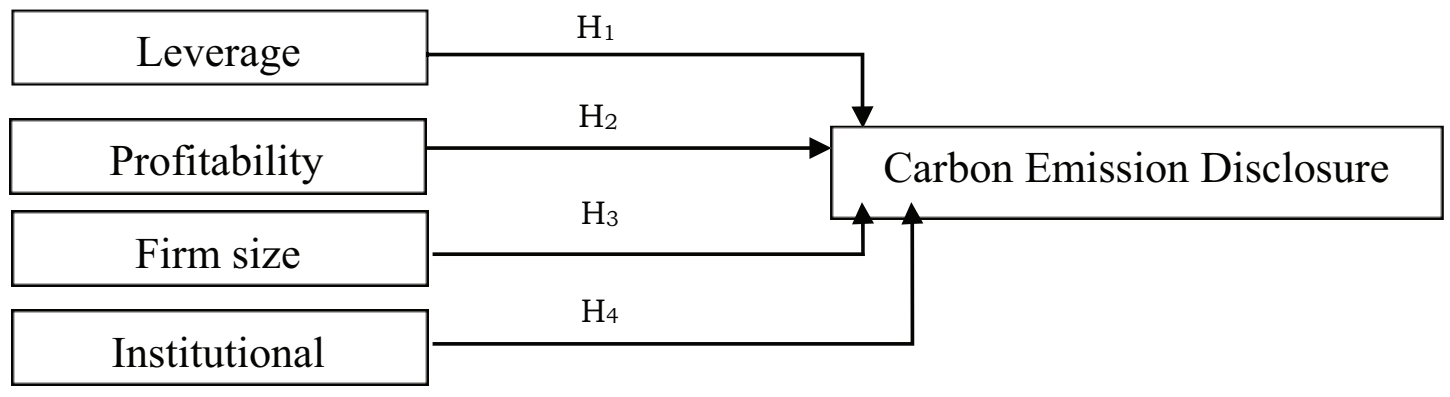

Figure 1: Research Model.

\section{Research Methodology}

This is a quantitative study with mining industry companies as research object. Population of this research is 41 mining companies listed in Indonesia Stock Exchange (IDX) and purposive sampling technique with defined criteria is employed to obtain the sample (Table 1). There are 14 companies that meet the criteria with 4 years observation period (2013-2016), thus there are 56 unit analysis. In addition, this study specifically examine carbon emission disclosure, leverage, profitability, firm size, and institutional 
ownership. Data is collected using documentation techniques from secondary data, including annual report and/or sustainability report from mining company listed in Indonesia Stock Exchange (BEI) during the period of 2013-2016.

TABLE 1: Criteria on Sample Selection.

\begin{tabular}{|c|c|c|}
\hline Description & No & Yes \\
\hline Total mining companies listed in Indonesia Stick Exchange & & 41 \\
\hline $\begin{array}{l}\text { Listed in Indonesia Stock Exchange during the period of } \\
2013-2016 \text {. }\end{array}$ & $(2)$ & 39 \\
\hline $\begin{array}{l}\text { Company publishes annual report and/or sustainability report } \\
\text { during the period of } 2013-2016 \text {. }\end{array}$ & & 39 \\
\hline $\begin{array}{l}\text { Company which does not disclose indicator to measure } \\
\text { carbon emission disclosure. }\end{array}$ & $(25)$ & 14 \\
\hline Sample based on the criteria & & 14 \\
\hline Year of observation & & 4 \\
\hline Total unit of analysis during the period of $2013-2016$ & & 56 \\
\hline
\end{tabular}

Data analysis methods used is descriptive statistical analysis, consists of maximum value, minimum value, mean, and standard deviation and inferential statistics by using multiple regression analysis with SPSS version 23 . Regression testing is also conducted for classical assumption test, there are normality test, autocorrelation test, multicolinearity test, and heteroscedasticity test. Operational definition of each variable is demonstrated in table 2.

TABLE 2: Operational Definition of Variables.

\begin{tabular}{|c|c|c|}
\hline Variable & Definition & Indicator \\
\hline $\begin{array}{l}\text { Carbon Emission } \\
\text { Disclosure }\end{array}$ & $\begin{array}{l}\text { The extent of environmental } \\
\text { responsibility information by } \\
\text { company which in this case related } \\
\text { to carbon emission [7]. }\end{array}$ & $\begin{array}{l}\text { Total item disclosed based on } \\
\text { research indicator by [7] }\end{array}$ \\
\hline Leverage & $\begin{array}{l}\text { Ratio to measure how much } \\
\text { company's liability pays the asset } \\
\text { [21]. }\end{array}$ & DAR $=\frac{\text { Total Liability }}{\text { Total Asset }}$ \\
\hline Profitability & $\begin{array}{l}\text { Company liability to gain profit from } \\
\text { business activity [6]. }\end{array}$ & ROA $=\frac{\text { Net Income After Tax }}{\text { Total Asset }}$ \\
\hline Firm size & $\begin{array}{l}\text { Firm size reflects company's } \\
\text { resources, bigger firm size } \\
\text { represents greater resources [7]. }\end{array}$ & Firm size = Ln (Total Asset) \\
\hline $\begin{array}{l}\text { Institutional } \\
\text { Ownership }\end{array}$ & $\begin{array}{l}\text { Concentrated ownership which is } \\
\text { measured by stock percentage of } \\
\text { institutional shareholder [15]. }\end{array}$ & $\mathrm{KI}=\frac{\text { Stock owned by institution }}{\text { Outstanding stock }}$ \\
\hline \multicolumn{3}{|c|}{ Source: Researcher Summary, 2018} \\
\hline
\end{tabular}

Checklist index for carbon emission disclosure is presented in Table 3. 
TABle 3: Carbon Emission Disclosure Checklist.

\begin{tabular}{|c|c|}
\hline Category & Item \\
\hline \multirow[t]{2}{*}{$\begin{array}{l}\text { 1- Climate change: risks and } \\
\text { opportunities }\end{array}$} & $\begin{array}{l}\mathrm{CC}_{1} \text { - assessment/description of the risks (regulatory, } \\
\text { physical or general) relating to climate change and } \\
\text { actions taken or to be taken to manage the risks }\end{array}$ \\
\hline & $\begin{array}{l}\text { CC2 - assessment/description of current (and future) } \\
\text { financial implications, business implications and } \\
\text { opportunities of climate change }\end{array}$ \\
\hline \multirow[t]{7}{*}{ 2-GHG emissions accounting } & $\begin{array}{l}\text { GHG1 - description of the methodology used to } \\
\text { calculate GHG emissions (e.g. GHG protocol or ISO) }\end{array}$ \\
\hline & $\begin{array}{l}\text { GHG2 - existence external verification of quantity of } \\
\text { GHG emission- if so by whom and on what basis }\end{array}$ \\
\hline & $\begin{array}{l}\mathrm{GHG}_{3} \text { - total GHG emissions - metric tonnes } \mathrm{CO}_{2} \text {-e } \\
\text { emitted }\end{array}$ \\
\hline & $\begin{array}{l}\text { GHG } 4 \text { - disclosure of Scopes } 1 \text { and 2, or Scope } 3 \text { direct } \\
\text { GHG emissions }\end{array}$ \\
\hline & $\begin{array}{l}\text { GHG5 - disclosure of GHG emissions by sources (e.g. } \\
\text { coal, electricity, etc.) }\end{array}$ \\
\hline & $\begin{array}{l}\text { GHG6 - disclosure of GHG emissions by facility or } \\
\text { segment level }\end{array}$ \\
\hline & $\begin{array}{l}\text { GHG7 - comparison of GHG emissions with previous } \\
\text { years }\end{array}$ \\
\hline \multirow[t]{3}{*}{ 3- Energy consumption Accounting } & $\begin{array}{l}\text { EC1 - total energy consumed (e.g. tera-joules or peta- } \\
\text { joules) }\end{array}$ \\
\hline & $\begin{array}{l}\text { EC2 - quantification of energy used from renewable } \\
\text { sources }\end{array}$ \\
\hline & EC3 - disclosure by type, facility or segment \\
\hline \multirow[t]{2}{*}{ 4- GHG reduction and cost } & $\begin{array}{l}\mathrm{RC} 1 \text { - detail of plans or strategies to reduce } \mathrm{GHG} \\
\text { emissions } \mathrm{RC} 2 \text { - specification of } \mathrm{GHG} \text { emissions } \\
\text { reduction target level and target year }\end{array}$ \\
\hline & $\begin{array}{l}\mathrm{RC}_{3} \text { - emissions reductions and associated costs or } \\
\text { savings achieved to date as a result of the reduction } \\
\text { plan } \mathrm{RC}_{4} \text { - cost of future emissions factored into } \\
\text { capital expenditure planning }\end{array}$ \\
\hline \multirow[t]{2}{*}{ 5- Carbon emission accountability } & $\begin{array}{l}\text { ACC } 1 \text { - indication of which board committee (or other } \\
\text { executive body) has overall responsibility for actions } \\
\text { related to climate change }\end{array}$ \\
\hline & $\begin{array}{l}\text { ACC2 - description of the mechanism by which the } \\
\text { board (or other executive body) reviews the } \\
\text { company's progress regarding climate change }\end{array}$ \\
\hline
\end{tabular}

\section{Results and Discussion}

Descriptive statistical results describe data of research variable, there are carbon emission disclosure (CED), leverage, profitability, firm size, and institutional ownership. Here is the description of each variable: 
TABle 4: Descriptive Statistic.

\begin{tabular}{l|c|c|c|c|c|} 
& $\mathrm{N}$ & Min. & Max. & Mean & Std. Deviation \\
\hline CED & 56 & 0,06 & 0,67 & 0,2414 & 0,17302 \\
\hline LEV & 56 & 0,10 & 1,90 & 0,5093 & 0,35831 \\
\hline PROF & 56 & $-0,64$ & 0,39 & 0,0260 & 0,14984 \\
\hline KI & 56 & 29,18 & 97,00 & 66,5303 & 18,76690 \\
\hline SIZE & 56 & 15,25 & 32,08 & 24,3280 & 5,33097 \\
\multicolumn{2}{l}{ Source: SPSS Output, 2018}
\end{tabular}

Based on Table 4, Carbon Emission Disclosure (CED) has minimum value of 0.06 , maximum value of $0.67,0.2414$ in average with standard deviation of 0.17302 . However, standard deviation value is under the mean value, thus data deviation is relatively small. This means that the variable is great because the sample is in the average area of the calculation.

In addition, leverage has minimum value of 0.10 , maximum value of 1.90 , an average value of 0.5093 with a standard deviation of 0.35831 . As CED, standar deviation in leverage is smaller that the average. Therefore, data deviation is considerably small. Meanwhile, profitability $-0.64,0.39$, and 0.0260 in its minimum, maximum and average respectively. Mean value of 0,0260 demonstrated that most mining companies in Indonesia has profit at $2,6 \%$ of its total asset. Furthermore, the standar deviation of profitability is 0,14984 which is higher than the average value. This data indicated that there is significant diffences among the data.

Data showed that firm size has minimum value of 15.25 , maximum value of 32.08 , while the average value is 24.3280 with a standard deviation of 5.33097 . Standard deviation which is below the average value means that discrepancies among data is relatively small. Moreover, institutional ownership has minimum value of 29.18 , maximum value of $97.00,66.5303$ in mean with standard deviation of 18.76690 which indicates that data deviation is considerably insignificant.

This study also run inferential statistical analysis including classical assumption test and multiple regression analysis with SPSS 23rd version. On classical assumption test, it is found that the data is not normally distributed, but other assumptions have been fulfilled. Even though various ways such as changing the data to another form are taken, normality test produce similar result. Therefore, this study employs multiple rank regression that goes into non-parametric domain. Furthermore, hypothesis is examined by observing significance value magnitude. If the value is less than 0.05 , 
hypothesis will be accepted. Table 5 demonstrates the results summary. However, regression equation in this study is:

$$
\begin{gathered}
R C E D=73,541-0,376 R \text { LEV }-0,346 R \text { PROF }-0,495 R \text { SIZE }-0,363 R \mathrm{KI}+\epsilon \\
\text { TABLE 5: Summary of Hypotheses Testing. }
\end{gathered}
$$

\begin{tabular}{|c|c|c|c|c|}
\hline No. & Hypotheses & $\begin{array}{c}\text { Beta } \\
\text { Coefficient }\end{array}$ & Sig. & Description \\
\hline 1. & $\begin{array}{l}\mathrm{H}_{1} \text { : Leverage has significant effect on carbon } \\
\text { emission disclosure }\end{array}$ & $-0,376$ & 0,002 & Accepted \\
\hline 2. & $\begin{array}{l}\mathrm{H}_{2} \text { : Profitability has significant effect on } \\
\text { carbon emission disclosure }\end{array}$ & $-0,346$ & 0,004 & Accepted \\
\hline 3. & $\begin{array}{l}\mathrm{H}_{3} \text { : Firm size has significant effect on carbon } \\
\text { emission disclosure }\end{array}$ & $-0,495$ & 0,000 & Accepted \\
\hline 4. & $\begin{array}{l}\mathrm{H}_{4} \text { : Institutional ownership has significant } \\
\text { effect on carbon emission disclosure }\end{array}$ & $-0,363$ & 0,003 & Accepted \\
\hline
\end{tabular}

\subsection{The effect of leverage on carbon emission disclosure}

First hypothesis examines the effect of leverage on carbon emission disclosure. Results showed that leverage has significant effect on carbon emission disclosure, thus hypothesis 1 is accepted. In addition, negative effect is found on the relation of these two. It means that higher leverage in Indonesian mining companies leads to lower carbon emissions disclosure by the company.

This finding supports stakeholder theory which states that the higher the level of corporate leverage, company will obtain great pressure from creditors to carry out its obligations that is paying off debt lent by creditors. Consequently, company

undertakes cost management by reducing carbon emissions disclosure. This cost management is conducted due to limited economic resources owned, hence company is required to choose between paying the obligation or performing voluntary disclosure [19]. This finding is in line with the results of researches by Jannah \& Muid (2014); Luo et al., (2013); Peng et al., (2014) who stated that leverage negatively affects carbon emission disclosure.

\subsection{The effect of profitability on carbon emission disclosure}

Second hypothesis examines the effect of profitability on carbon emission disclosure. Results indicated that profitability has significant effect on carbon emission disclosure. 
The relationship is found to be negative. It means that higher level of profitability of mining companies in Indonesia directs to lower carbon emissions disclosure by the company.

This results does not support the theory of legitimacy which states that better company performance encourage company to expose more of its voluntary disclosure, including carbon emissions disclosure. Moreover, this finding is also in contrary to Akhiroh \& Kiswanto (2016); Cahya (2016); Jannah \& Muid (2014) who demonstrated that profitability has positive effect on carbon emission disclosure. However, the results of this study is consistent to Yanto \& Muzzammil (2016) finding that profitability has negative and significant impact on environmental disclosure.

Yanto \& Muzzammil (2016) argued that there are reasons for negative impact of profitability on environmental disclosure. First, environmental disclosure in Indonesia is voluntary. In addition, Monitory Agency for Capital Market and Financial Institutions (BAPEPAM-LK) does not determine environmental disclosure as one of the requirements in Indonesia Stock Exchange. Second, companies with low profitability take advantage of environmental disclosure for legitimacy purposes. Conversely, companies with high profitability do not need to expand their environmental disclosure as it may disrupt financial achievement of the company [17].

\subsection{The effect of firm size on carbon emission disclosure}

Third hypothesis investigates the effect of firm size on carbon emission disclosure. It is found that firm size affects carbon emission disclosure, therefore hypothesis 3 is accepted. Specifically, the effects between these two is negative. This finding indicated that bigger firm of Indonesian mining companies tends to disclose more limited information of its carbon emission disclosure.

This finding conctradicts the theory of legitimacy which states that companies with larger size have a greater tendency to disclose information about carbon emissions. However, the results support Dibia \& Onwuchekwa (2015) who showed that there is negative relationship between firm size and disclosure of oil and gas companies in Nigeria. There are several argument regarding this finding. First, big companies become more vulnerable to political attacks such as pressure for social responsibility implementation, as well as subject to larger regulations such as price controls and high corporate taxes. Therefore, company reacts to not being attention center related to its published information. That is why large company tends to disclose less detailed 
information in annual reports (Wallace \& Nasser, 1995 in [24]). Second, smaller companies among others in the same industry will have huge motivation to compete. Hence, those companies may produce more information including voluntary disclosure to attract potential investors.

\subsection{The effect of institutional ownership on carbon emission disclosure}

Fourth hypothesis examines the effect of institutional ownership on carbon emission disclosure. Results showed that institutional ownership has significant effect on carbon emission disclosure. In addition, the impact is found to be negative. Therefore, higher institutional ownership in Indonesian mining company encourage company to reduce its carbon emission disclosure. This means that the higher the

level of presentation of institutional ownership in mining companies in Indonesia, the lower disclosure of carbon emissions by companies.

The results do not support agency theory which states that institutional ownership can be an effective control mechanism in every decision taken by management. However, this study is consistent with studies by Ezhilarasi \& Kabra (2017) and Lakhal (2005) who found that there is negative relationship between institutional ownership and to the extent its company's environmental disclosure. Furthermore, Alhazaimeh et al. (2014) also demonstrated that there is negative relationship between institutional ownership and voluntary disclosure. This condition occurred due to low pressure of institutional owner to make voluntary disclosure. Institutional owners as majority shareholder have great authority to encourage company not to make voluntary disclosures as they want to maximize their profits. Nevertheless, according to agency theory, such action will lead to agency issues between the majority shareholder and minority shareholder due to unknown corporate information by minority shareholders.

\section{Conclusion}

Results indicated that leverage, profitability, firm size, and institutional ownership significantly affect carbon emission disclosure. Hence, all hypotheses are accepted. Moreover, further researchers is recommended to measure carbon emission disclosure using other indicators which have been adapted into Indonesian conditions, such as those indicators used by Jaggi et al. (2017) in his research entitled The Factors 
Motivating Voluntary Disclosure of Carbon Information: Evidence Based On Italian Listed Companies. In addition, determination coefficient of the study is less than $50 \%$, thus future research may investigates other factors that affect carbon emission disclosure, such as environmental performance, firm age, media exposure, and growth opportunity.

\section{References}

[1] Akhiroh, T., \& Kiswanto, K. (2016). The Determinant Of Carbon Emission Disclosures. Accounting Analysis Journal, 5(4), 326-336.

[2] Alhazaimeh, A., Palaniappan, R., \& Almsafir, M. (2014). The impact of corporate governance and ownership structure on voluntary disclosure in annual reports among listed jordanian companies. Procedia-Social and Behavioral Sciences, 129, 341348.

[3] Andriyani, R., \& Khafid, M. (2014). Analisis Pengaruh Leverage, Ukuran Perusahaan Dan Voluntary Diclosure Terhadap Manipulasi Aktivitas Riil. Accounting Analysis Journal, 3(3), 273-281.

[4] Anggraeni, D. Y. (2015). Pengungkapan Emisi Gas Rumah Kaca, Kinerja Lingkungan, Dan Nilai Perusahaan. Jurnal Akuntansi Dan Keuangan Indonesia, 12(2), 188-209.

[5] Atikah. (2018). Hubungan "Global Cooling" dan "Global Warming" Terhadap Perubahan Iklim. Retrieved from https://www.kompasiana.com/ismahatikahk/ 5a7c7ed5cbe523597a135214/hubungan-global-cooling-dan-global-warmingterhadap-perubahan-iklim

[6] Aulia, F. Z., \& Agustina, L. (2015). Pengaruh Karakteristik Perusahaan, Kinerja Lingkungan, Dan Liputan Media Terhadap Environmental Disclosure. Accounting Analysis Journal, 4(3), 1-8.

[7] Bae Choi, B., Lee, D., \& Psaros, J. (2013). An analysis of Australian company carbon emission disclosures. Pacific Accounting Review, 25(1), 58-79.

[8] Cahya, B. T. (2016). Carbon Emission Disclosure: Ditinjau dari Media Exposure, Kinerja Lingkungan dan Karakteristik Perusahaan Go Public Berbasis Syariah di Indonesia. Nizham Journal of Islamic Studies, 4(2), 170-188.

[9] Chang, K., \& Zhang, L. (2015). The effects of corporate ownership structure on environmental information disclosure-empirical evidence from unbalanced penal data in heavy-pollution industries in China. WSEAS Transactions on Systems and Control, 10, 405-414. 
[10] Dewi, S. P., \& Chandra, J. S. (2016). Pengaruh Pengungkapan Sukarela, Asimetri Informasi, dan Manajemen Laba Terhadap Cost of Equity Capital Pada Perusahaan Manufaktur. Jurnal Bisnis Dan Akuntansi, 18(1), 25-32.

[11] Dibia, N. O., \& Onwuchekwa, J. C. (2015). Determinants of Environmental Disclosures in Nigeria: A Case Study of Oil and Gas Companies. International Journal of Finance and Accounting, 4(3), 145-152.

[12] Dowling, J., \& Pfeffer, J. (1975). Organizational legitimacy: Social values and organizational behavior. Pocific Sociological Review, 18(1), 122-136.

[13] El-Diftar, D., Jones, E., Ragheb, M., dan Soliman, M. (2017). Institutional investors and voluntary disclosure and transparency: the case of Egypt. Corporate Governance: The International Journal of Business in Society, 17(1), 134-151.

[14] Ezhilarasi, G., \& Kabra, K. C. (2017). The Impact of Corporate Governance Attributes on Environmental Disclosures: Evidence from India. Indian Journal of Corporate Governance, $10(2), 24-43$.

[15] Fortunella, A. P., \& Hadiprajitno, P. B. (2015). The Effects Of Corporate Governance Structure And Firm Characteristic Towards Environmental Disclosure. Diponegoro Journal Of Accounting, 4(2), 717-727.

[16] Hermawan, S., \& Maf'ulah, A. N. (2014). Pengaruh Kinerja Keuangan Terhadap Nilai Perusahaan Dengan Pengungkapan Corporate Social Responsibility Sebagai Variabel Pemoderasi. Jurnal Dinamika Akuntansi, 6(2), 103-118.

[17] Irwhantoko, I., \& Basuki, B. (2016). Carbon Emission Disclosure: Studi pada Perusahaan Manufaktur Indonesia. Jurnal Akuntansi Dan Keuangan, 18(2), 92- 104.

[18] Jaggi, B., Allini, A., Macchioni, R., \& Zagaria, C. (2017). The factors motivating voluntary disclosure of carbon information: Evidence based on Italian listed companies. Organization dan Environment, oo(0), 1-25.

[19] Jannah, R., \& Muid, D. (2014). Analisis Faktor-Faktor Yang Mempengaruhi Carbon Emission Disclosure Pada Perusahaan Di Indonesia (Studi Empiris Pada Perusahaan Yang Terdaftar Di Bursa Efek Indonesia Periode 2010-2012). Diponegoro Journal of Accounting, 3(2), 1000-1010.

[20] Jensen, M. C., \& Meckling, W. H. (1976). Theory of the firm: Managerial behavior, agency costs and ownership structure. Journal of Financial Economics, 3(4), 305-360.

[21] Kasmir. (2012). Analisis Laporan Keuangan. Jakarta: Raja Grafindo Persada. Lakhal, F. (2005). Voluntary earnings disclosures and corporate governance:

[22] Evidence from France. Review of Accounting and Finance, 4(3), 64-85. 
[23] Luo, L., Tang, Q., \& Lan, Y. (2013). Comparison of propensity for carbon disclosure between developing and developed countries: A resource constraint perspective. Accounting Research Journal, 26(1), 6-34.

[24] Maimako, S. S., \& Ayila, U. R. (2015). Association between Firm Size Firm Effects and the Extent of Compliance with Accounting Standards Disclosures by Government Business Enterprises in Nigeria. International Journal of Business and Social Science, 6(11), 138-156.

[25] Majid, R. A., \& Ghozali, I. (2015). Analisis Faktor-Faktor Yang Mempengaruhi Pengungkapan Emisi Gas Rumah Kaca Pada Perusahaan Di Indonesia. Diponegoro Journal of Accounting, 4(4), 381-391.

[26] Marwati, C. P., \& Yulianti, Y. (2015). Analisis Pengungkapan Sustainability Report Pada Perusahaan Non-Keuangan Tahun 2009-2013. Jurnal Dinamika Akuntansi, 7(2), 167-181.

[27] Nainggolan, N., \& Solikhah, B. (2017). Pengaruh Asset Growth, Leverage Dan Earning Variability Terhadap Risiko Sistematik. Accounting Analysis Journal, 5(2), 86-93.

[28] NASA (2018) 'Carbon Dioxide Levels in The Air at Their Highest in 650,000 Years'. Available at: https://climate.nasa.gov/.

[29] Peng, J., Sun, J., \& Luo, R. (2014). Corporate Voluntary Carbon Information Disclosure: Evidence from China's Listed Companies. The World Economy, 38(1), 91-109.

[30] Prado-Lorenzo, J.-M., Rodríguez-Domínguez, L., Gallego-Alvarez, I., \& GarcíaSánchez, I.-M. (2009). Factors influencing the disclosure of greenhouse gas emissions in companies world-wide. Management Decision, 47(7), 1133-1157.

[31] Purnamasari, I. C., \& Suhermin, S. (2017). Corporate Social Responsibility, Kepemilikan Institusional, Dan Kepemilikan Manajerial Terhadap Nilai Perusahaan. Jurnal IImu dan Riset Manajemen, 6(3), 1-16.

[32] Sulistyono. (2012). Pemanasan Global (Global Warming) dan Hubungannya dengan Penggunaan Bahan Bakar Fossil. Forum Teknologi, 2(2), 47-56.

[33] Supriadi, A., Oktaviani, K., Kencono, Agung Wahyu Prasetyo, B. E.『;, \& Kurniasih,

[34] T. N. (2016). Dato Inventory Emisi GRK Sektor Energi. Jakarta Pusat.

[35] WRI Indonesia | Making Big Ideas Happen (2018). Available at: http://www.wriindonesia.org/

[36] Yanto, H., \& Muzzammil, B. S. (2016). A Long Way To Implement Environmental Reporting In Indonesian Mining Companies. Ijaber, 14(10), 6493-6514. 